\title{
DEMOCRATIC CIVIL SOCIETY AND THE ESSENCE OF ITS CONTENT
}

\author{
Khakima Davlatova \\ Master Student Jizzakh State Pedagogical Institute Jizzakh region, Uzbekistan \\ Ozodbek Nematov \\ Student Faculty Of History National University Of Uzbekistan Named After Mirzo Ulugbek, \\ Uzbekistan
}

\begin{abstract}
BSTRACT: This article discusses Democratic civil society, its legal, economic, political and spiritual foundations. The stages and features of the formation of civil society in Uzbekistan will be discussed. Citizens' self-government bodies and its types are discussed. Also in the article are Open Civil Society and the Rule of Law. The program of political construction "From a strong state - to a strong civil society" will be considered.
\end{abstract}

EY WORDS: Democratic civil society, market economy, democratic, totalitarian, Constitution, activities, service, military, family duties, social, labor.

\section{NTRODUCTION}

In a democratic civil society, a market economy based on multi-sectoral competition, enterprising entrepreneurs form the basis of economic development the interests of different social strata are balanced. In a democratic civil society, the responsibilities of citizens to the state are mainly to obey the law and pay taxes. Of course, in certain situations, citizens also have responsibilities related to their social, labor, entrepreneurial activities, service, military, family duties. But in this system, it is mainly the horizontal connections that predominate, not the vertical connections. There are also two other principles that prevail in a democratic civil society. According to the first, everyone remains a free and equal citizen until he is found guilty by a court. Second, every free citizen can act as he wishes within the law, without contradicting the law and ethics. According to the first principle, if a person's guilt is not legally proven, he or she is always considered honest, correct, and innocent. According to the second principle, a free citizen can commit any act that is not contrary to law and ethics. Thus, a democratic civil society free from the domination of politics and ideology, a person, a citizen, a person occupies a central place in an open, democratic, totalitarian, internally developing democratic civil society. In this sense, a democratic civil society is the opposite of a political and ideological one, especially an authoritarian one.

Different views and theories about the essence of a democratic civil society, which have been formed over the centuries, have always resisted the violation of human rights. From the ancient traditions of "tribal democracy" based on natural and customary law, to the "Babylonian laws" of ancient Babylon, the "Avesto" norms and the Zoroastrian teachings based on them, the first information about the primitive and cosmic forms of democratic civil society is given.

\section{ATERIAL AND METHODS}

The philosophical and political-legal teachings of such 
Oriental Journal of History, Politics and Law Vol.1 (1), pp.09-13, 23 May, 2021 Available online at http://supportscience.uz/index.php/ojhpl (C) 2021 Support Science LLC

DOI: https://doi.org/10.37547/supsci-ojhpl-01-03

thinkers of mankind as Aristotle, Plato, Confucius, as well as the great scholars of the East - Farobi, Ibn Sina, Beruni, Yusuf Khas Hajib and other encyclopedic intellectuals, related to the formation of a democratic civil society legal, theoretical ideas are expressed.

Thomas Gobbs (1588-1679) of England was the first to introduce the term "civil society" into science, and the most influential principle of the legal management of social relations by interpreting human freedom in civil society as the right to do anything not prohibited by law laid the foundation. The classical theorist of civil society, Georg Wilhelm Friedrich Gegel (1770-1831), in his Philosophy of Law, created a holistic doctrine of the three legal foundations of civil society (economic basis, political basis, spiritual basis). At the time when these principles were mentioned, no state had any Constitution or legal resources. In the process of its democratic development, humanity has discovered the value of discovering the Constitution, defining its life on a clear constitutional and legal basis. That is why it is impossible to imagine today's democratic civil society without these values. This democratic factor set another - the fourth (actually the first) constitutional foundation of civil society. It is known that the status of the state, which is a political and social institution of modern society, is first of all reflected in its Constitution. The constitutional status of the state determines the status of society. Simply put, just as the state is, so is society. Because only a just society can be a civil society, therefore, the Constitution of the state is also the Constitution of society. This means that a democratic civil society, naturally, will have its own constitutional and legal basis. The economic basis of civil society is based on private property. Private property is formed and exists only in a democratic society, free, open, capable of internal development, non-politicized, free from any ideology, that is, ideological monopoly.

Historical experience has shown that private property socially alienates people and at the same time unites them. Ultimately, it is private property that allows for the formation of a democratic civil society that is completely independent of state power.

A democratic civil society is an independent producer, an independent free buyer, an independent free civil society. It is private property that is a key factor in the democratic reform of society. The private owner has the right to say "no" to the state at any time, at his own discretion and ability, under the relevant laws. This right allows him not to be deprived of his material means.

While producers are a particular part of society, consumers are the whole of society. Every citizen, who is a consumer of material and spiritual goods, will be peaceful, stable and prosperous only if he is well-off and there is no shortage of consumption. The administrative authorities are trying to take the initiative in order to prevent protests and instability. As a result, the consumer becomes completely dependent on administrative authority. It will no longer be a democratic civil society, but a totalitarian society. In the policy of liberalization of the process of formation of civil society in Uzbekistan, first of all, strong mechanisms to educate citizens with high political consciousness, thinking, worldview, deep political culture, therebystrengthening the political activity of the population, ensuring a balance between interests and opposing forces in society began to take shape. It creates real conditions and a legal basis for ensuring the right of citizens to vote, to freely express their will, to realize and protect their interests. To this end, in the mid-1990s, he developed a program of political construction "From a strong state - to a strong civil society" and began to ensure its practical implementation. The practical effect is obvious today: multi-party society has emerged, political pluralism has been established, the legal and practical basis for more free democratization of the media has been created, and a deep political culture has been nurtured and formed. Article 13 of the Constitution of the Republic of Uzbekistan states that "democracy in the Republic of Uzbekistan is based on universal principles", the Preamble to the Basic Law states that "recognition of the supremacy of universally recognized rules of international law" is the constitutional goal of the people of Uzbekistan. Based on this, the interdependence of national and universal values, universal values are a priority in determining the foundations of civil society in Uzbekistan. This can be seen, in particular, in the concrete practical results of the national idea and its status as a holistic logicalcontent essence related to universal values.

- conomic freedom, various forms of property, market relations;

- recognition and protection of natural human and civil rights;

- freedom and democratic nature of power;

- equality before the law and justice, the necessary legal protection of the individual;

- the rule of law based on the separation of powers and the interaction between them;

- political and ideological pluralism, the existence of open opposition;

- freedom of speech and press;

- non-interference of the state in the private lives of citizens, mutual responsibilities and obligations between them; 
Oriental Journal of History, Politics and Law Vol.1 (1), pp.09-13, 23 May, 2021 Available online at http://supportscience.uz/index.php/ojhpl (C) 2021 Support Science LLC

DOI: https://doi.org/10.37547/supsci-ojhpl-01-03

- social stability, peace, cooperation and national accord;

- An effective social policy that provides people with a decent life.

The spiritual image of any society depends on the system of that society, on what ideas and goals it pursues, on what thinking it decides. The path chosen by Uzbekistan is the formation of a democratic, civil society in which the interests of the people are fully protected and their rights are fully guaranteed. As Uzbekistan chooses to build a democratic, civil society, the first stage of the democratization process is the preparation of citizens as active participants and defenders of the democratic process in the context of liberalization of the political sphere. As Uzbekistan chooses the path of building a democratic civil society, it is necessary to reform all the vices associated with the colonial era in the minds and hearts of the people, to "renew" the living, the existing man, to "repair" them spiritually. And so on. This is a great event that requires great political power, political culture and political will from any state.

After all, the importance of political reforms in our country is that now all the conditions have been created to increase the intention to form a democratic civil society, to implement the most important aspects of democracy. Citizens now have to participate in the process of political decision-making through the activities of public organizations that express their political will and interests, or directly. Experiences of the independence period, Analyzing the specifics, achievements and shortcomings of building a civil society in Uzbekistan, as well as the experience of leading foreign countries, he said: "It is known that in any society there are at least three criteria that determine the level of democracy. These are how much the people are aware of the decision-making process, how much government decisions are controlled by the people, how much ordinary citizens are involved in governing the state. Today, selfgoverning bodies are gradually being given some of the powers previously exercised by state bodies. Take measures to preserve and dispose of ownerless property, as well as inherited property, notify conscripts, collect taxes, insurance, utility bills and other payments. 'to make proposals to the relevant state bodies on collusion, change the boundaries of mahallas and change the names of other entities, to consider the allocation of land plots and to provide financial assistance to low-income families and $p$ Assignment of benefits to needy families with children, registration of civil status and acts, as well as the approval of wills, power of attorney in the absence of a notary in the settlement, taking measures to protect the inherited property, quarterly district, hearings of reports of heads of city and regional khokimiyats on issues within the scope of activities of citizens' selfgovernment bodies, weddings, etc. making recommendations on the conduct of ceremonies, and so on. It is known that one of the priorities in the process of forming a democratic state governed by the rule of law and an open civil society is the gradual transfer of powers of central government to local governments and public organizations and the comprehensive strengthening of citizens' selfgovernment. . Thus, the formation and improvement of the work of governing bodies in a new context has expanded the participation of citizens in the affairs of state and society and increased their political activism. This indicates that the process of democratization in our society is deepening and moving "from a strong state to a strong civil society".

Ideally, those who envision civil society say that it is an open, just society in which free and equal people live, have their own civil and political rights, take an active part in governing the state, and express their views openly. that is, to meet their needs in all respects, to form associations and organizations that meet their goals. An open society is a democratic society with economic, political, cultural pluralism, civil society and the rule of law, developed in a number of sociophilosophical doctrines. However, there is no clear definition of an open society. in many cases it is preferable to see an open society as a reflection of a pre-capitalist society or a closed socialist society. There are elite and egalitarian notions of an open society. According to the elite theory, an antagonism based on an open society, that is, an ideal social system in which international human solidarity, universal, anti-totalitarian morality, freedom of the individual and creativity prevail, and a specific ascetic humanism, lies. The egalitarian theory stems from the reality of the confrontation between the open society and the closed society in modern times. For a society, its existence and status is a totalitarian society determined by law. It is characterized by the interests of society over the interests of the individual, personal irresponsibility, ideological dogmatism. It is a tribalistic, that is, a society similar to the primitive tribal system that sets itself against the whole world.

For members of an open society, on the contrary, a rational-critical approach, the ability to purposefully and consciously manage social development, is characterized by the gradual formation of state institutions in accordance with the needs of the people. According to the egalitarian view, Western democracy has largely shifted to an open society. Nevertheless, according to K.R. Popper, Western democracy cannot be called a fully open society. Thus, the views of 
Oriental Journal of History, Politics and Law Vol.1 (1), pp.09-13, 23 May, 2021 Available online at http://supportscience.uz/index.php/ojhpl (C) 2021 Support Science LLC

DOI: https://doi.org/10.37547/supsci-ojhpl-01-03

Western democracy on open society, J. Soros, clearly showed that a balance between the economic and social components of social development is absolutely necessary. This can only be achieved within a civil society with strong community structures.

It is difficult to achieve such a balance without civil society. The balance between social and market values can be ensured only if civil society, with its status, fully meets all the requirements of an open society, which is always open to progressive change, promising endless perfection.

Civil society is manifested both as a practical reality as a form of social development and as an ideal that serves the direction of social development. Real civil society is compatible with an ideal civil society only if the rule of law is established. Ideal civil society is based on the rule of law in society, the freedom of the people their equality in law by nature.

At the same time, members of society consciously and voluntarily assume certain responsibilities and obey general laws. In a state governed by the rule of law, civil society becomes the source of law. It determines the status of the state. In such a situation, the individual will have priority over society with his rights. Therefore, the rule of law is a form of formation and functioning of state power based on the interaction of individuals and various associations on the basis of these legal norms. At present, the basic classification of the rule of law is clearly defined. First of all, the economic basis of the rule of law is based on the multisectoral, equal relations of different forms of property (state, collective lease, private cooperative, etc.), production relations based on equal legal protection. In a state governed by the rule of law, property belongs directly to producers and consumers of material goods. The individual producer is manifested as the owner of the fruit of his own labor. The legal basis of statehood exists only in the conditions of independence and freedom of property. Such free, honest property ensures the rule of law, the equality of the participants in production relations, the growth of the welfare of society and its economic development. The moral basis of the rule of law defines the universal principles of humanism, equality and freedom of citizens. This is clearly reflected in the democratic methods of governing the state, in justice and fairness, in the priority of individual rights and freedoms in relations with the state, in the protection of minority rights, and in tolerance for different religious worldviews.

The rule of law is an independent state that embodies the sovereignty of the peoples, nations and peoples living in the country. The rule of law, which exercises the supremacy, completeness and stability of power, ensures free social relations based on justice, which is considered an exception for all citizens. In a state governed by the rule of law, coercion is based on law.

Illegal acts and violence are not allowed in this country. The state uses force within the law only if its sovereignty violates the interests of citizens. When a person's behavior threatens the freedom of others, his freedom is restricted by law.

Based on the above basic descriptions, there are the following main features of the rule of law:

First, the rule of law in all spheres of social life, after all, the supremacy of the law, first of all, the Constitution, creates in society a strong regime of the rule of law, a fair legal order.

Second, the rule of law has a positive impact on the rights of the individual in relation to his interests and inviolability, including the right to education, social protection, judicial protection, and so on. The level of development of individual freedom is determined by the legal maturity of the state, the economic and moral foundations.

Third, the mutual responsibilities of the state and the individual to each other, the legal status of mutual responsibility between the state and the individual is an important component.

In a state governed by the rule of law, the organization of the state's activity in such a status plays an important role. The organization and functioning of the rule of law is based on the principle of the existence of legislative, executive and judicial powers. The three branches of government operate only within their constitutional status. Citizens themselves control the activities of all branches of government through the general electoral system. The rule of law has a number of common legal foundations that unite all members of civil society and are universal values in their essence.

\section{ONCLUSION}

In general, the role of the rule of law in civil society is great. Therefore, every member of an open civil society must strive to have their own personal property or to become the owner of that property. The rule of law is distinguished by another important aspect as a component of open civil society. It is through this that the integration of the state in the process of globalization becomes clear. Indeed, the activities and life of an open civil society, formed on the basis of the rule of law, have a direct global content. And so the rule of law is, in its essence, a political expression of civil society. Their relationship is a shawl and content 
Oriental Journal of History, Politics and Law Vol.1 (1), pp.09-13, 23 May, 2021 Available online at http://supportscience.uz/index.php/ojhpl (C) 2021 Support Science LLC

DOI: https://doi.org/10.37547/supsci-ojhpl-01-03

ratio. The inseparability and integration of this form and content is a symbol of the integrity of society.

This means that Uzbekistan has the legal basis for the rule of law and the conditions for the formation of a strong civil society. Now it is reasonable to assume that the creation of perfect mechanisms for the implementation of these strong policy principles is one of the most important tasks. A strong civil society is a strong state that overcomes any obstacles to innovation, maintains a stable system of governance in building a nation-state and modernizing the economy, maintains stability, carefully and gradually implements reforms, and is trusted by the people.

\section{EFERENCES}

1. Shodiev N. Uzbekistan at the stage of national recovery. Moscow: Vega, 1999.

2. Shodiev N., Eofurov 3., Siddikov B. National ideology and idea. Tashkent: Uzbekistan, 1996.

3. Gafurov Z., Toshev S. Spiritual foundations of independence. Against: Nasaf, 1994.

4. Gafurov Z., Siddikov B. Spiritual growth is a factor of development. Tashkent: TDTU, 1997.

5. Gafurov Z., Siddikov B. Spiritual and enlightenment rise of national independence. Tashkent: TDTU,2000.

6. Tulenov J., Kadyrov B., Gofurov Z. Towards spiritual growth. Tashkent: Mehnat, 2000.

7. The stars of spirituality. Tashkent: Abdulla Qodiri Publishing House, 1999.

8. Alpomish. Tashkent: Sharq, 1998. Jaloliddin Manguberdi. Tashkent: Sharq, 1999.

9. Shodiev N. National idea: how to see it in Uzbekistan. // Trud, June 23, 2000.

10. Каримов, Н. Р. (2018). ВКЛАД МУХАММАДА МАНСУРА АЛИ В ИЗУЧЕНИЕ НАУЧНОГО НАСЛЕДИЯ АБУ ИСА ТЕРМИЗИ. In НАУКА И ИННОВАЦИИ В ХХІ ВЕКЕ: АКТУАЛЬНЫЕ ВОПРОСЫ, ОТКРЫТИЯ И ДОСТИЖЕНИЯ (pp. 198-200).

11. Rustamiy, S., Lutfullaeva, D., \& Gulomova, H. (2020). THE IMPORTANCE OF BALAGHA SCIENCE IN AESTHETIC EDUCATION. PalArch's Journal of Archaeology of Egypt/Egyptology, 17(6), 8882-8886.

12. Каримов, Н. Р. (2018). КРАТКИЙ ОБЗОР РАБОТ БЕРУНИ И ЕГО РОЛИ В ЧЕЛОВЕЧЕСКОЙ ЦИВИЛИЗАЦИИ. In Лучшая студенческая статья 2018 (рр. 85-91).

13. Rustamiy, S. A. (2020). Content of components of the science balagat. ACADEMICIA: An International Multidisciplinary Research Journal, 10(10), 1332-1337.
14. Дониёров, А. Х., \& Каримов, Н. Р. (2018). " КИТАБ АЛ-ХИКМА" И" ХИКМА" В НАУЧНОМ НАСЛЕДИИ ХАКИМА ТИРМИЗИ. In ЛУЧШАЯ НАУЧНАЯ СТАТЬЯ 2018 (рр. 48-52).

15. Khudoyberdiyevich, D. A., \& Rakhmonkulovich, N. K. (2018). The contribution of sarah sviri to the study of the scientific heritage of hakim tirmidhi. ACADEMICIA: An International Multidisciplinary Research Journal, 8(11), 6067.

16. Rustamiy, S. A. (2020). Content of components of the science balagat. ACADEMICIA: An International Multidisciplinary Research Journal, 10(10), 1332-1337.

17. SAIDAZIMOVA, U. T. (2021). The issue of two women in the korean art world. Journal of Contemporary Issues in Business and Government, 27(3), 303-308.

18. Saydazimova, U., \& Murodova, D. (2021). In Lee Bom Son's Story "Stray Bullet", the Issue of the Negative Consequences of the Civil War is Highlighted. Psychology and Education Journal, 58(1), 1138-1144.

19. Umida, S. (2019). Special genres in Korean and Uzbek literature: Their similarities and specific features. International Journal of Scientific and Technology Research, 8(12), 1264-1268. 